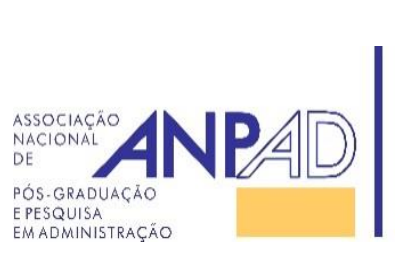
Available online at
http://www.anpad.org.br/bar
BAR, Rio de Janeiro, v. 13, n. 4, art. 6, e160083, Oct./Dec. 2016
http://dx.doi.org/10.1590/1807-7692bar2016160083

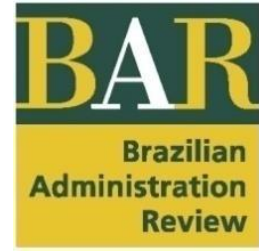

\title{
Internal Corporate Social Responsibility and Performance: A Study of Publicly Traded Companies
}

Flávia Cavazotte ${ }^{1}$ Nicolas Corteze Chang ${ }^{1}$

Pontifícia Universidade Católica do Rio de Janeiro/IAG ${ }^{1}$

Received 31 August 2016; received in revised form in 24 November 2016; accepted in 25 November 2016; published online 14 December 2016.

Editor's note. José Carlos Lázaro Silva Filho served as Action Editor for this article. 


\begin{abstract}
Research on the relationship between social responsibility and the financial performance of companies has yielded ambivalent results. Since investments on different areas of social responsibility can promote distinct outcomes, in this study we focus on internal corporate social responsibility (I-CSR), that is, investments on employees. The objective of the study is to verify if outlays on I-CSR affect organizational performance. We analyzed financial information from companies listed in the São Paulo Stock Exchange, and their social balance sheets filled with the Brazilian Institute of Social and Economic Analysis between 2001 and 2007, applying Two-Stage Least Squares (2SLS) equation model to minimize endogeneity and reverse causality problems. The results indicate that overall I-CSR was associated with revenue contemporarily, one and two years after the investments. Corporate outlays on healthcare, pension plans, employee education and profit-sharing all had positive effects on revenue in the years that followed such investments.
\end{abstract}

Key words: corporate social responsibility; internal social responsibility; human capital; financial performance; organizational performance. 


\section{Introduction}

Within the realm of corporations, the idea that a firm's single purpose is to make profits has dictated the way businesses are conducted by most organizations, leading to a mindset focused on short term results, with less attention given to most business stakeholders. Nevertheless, large corporations play important roles within local and global economies that include generating jobs, paying taxes and creating value for consumers and society (Jenkins, 2007), and a narrow-minded focus on profit maximization at the expenses of stakeholders can hurt company performance and future returns (Aguinis, 2011).

Besides discussing how and when companies are socially responsible, scholars have also explored the impacts that social responsibility initiatives have on businesses themselves (Aguinis \& Glavas, 2012; Campbell, 2007). Some have suggested that CSR can positively affect firms financially, by promoting improved relations with their stakeholders, thereby reducing transaction costs, production costs and certain associated risks (Barnett, 2007). However, findings from empirical research thus far conducted on that matter are ambivalent: while some report that CSR has a positive influence on the financial performance of firms (e.g.: Orlitzky, Schmidt, \& Rynes, 2003; Peloza \& Shang, 2011), others have observed non-significant or even negative effects (e.g.: Brammer, Brooks, \& Pavelin, 2006; Margolis \& Elfenbein, 2008).

After reviewing research on the subject, Aguinis and Glavas (2012) concluded that yet very little is known about the processes through which such investments can lead to improved performance at the organizational level of analysis. Quite clearly, outlays on different areas of social responsibility (e.g., internal, environmental or philanthropic initiatives) can produce distinct outcomes in terms of costs and returns (Van der Laan, Ees, \& Witteloostuijn, 2008). Therefore, in the present study we single out internal CSR investments (I-CSR), a dimension of social responsibility that focuses on employees (Carroll, 2008; Turker, 2009). Would investments in I-CSR lead to increments in company performance in the short and long run?

Although evidence obtained over the last decades has suggested that investments on employees, such as sponsoring development and training, can promote more efficient and effective company operations and processes (e.g.: Chen \& Huang, 2009), we still lack consistent research on the outcomes from outlays on specific dimensions of internal social responsibility on company performance (Aguinis \& Glavas, 2012; Weber, 2008). The objective of this research is to analyze if company expenditures on internal dimensions of social responsibility can affect present and future revenue.

In this article, we begin by presenting a theoretical framework regarding how I-CSR outlays would promote revenue growth, and by highlighting specific facets of internal social investments that are likely to drive such outcomes. Since most studies on CSR and company performance use panel and level regression analysis, without accounting for the biases associated with endogeneity and reverse causality (see: Ree \& Carretta, 2006), in the methods section we describe how we applied 2SLS in our study - a technique that corrects for such problems, frequently employed in Economics (Wooldridge, 2002). We present the results of the analyses in the following section, based on longitudinal data from companies traded in the Brazilian stock exchange during the last decade. In the conclusion, we discuss our findings vis-à-vis extant research, highlighting implications for practice and presenting an agenda for future research in the field.

\section{Literature Review}

Because of the socioeconomic transformations that many firms have undergone in recent years, corporate social responsibility (CSR) has attracted increasing interest in the business and academic spheres (Aguinis \& Glavas, 2012; Waddock, 2004). Several broad-ranging conceptualizations of CSR 
have been put forward, aimed at defining the set of elements that characterize a socially responsible company - expressions such as contribution to society and commitment to sustainable development are invariably included among these elements. For instance, the World Bank's view is that corporate social responsibility refers to

companies' commitment to contributing to sustainable economic development in their relations with their employees, with the communities in places where they operate, and with society as a whole, so that their actions have a positive effect on business and on development (World Bank, 2003, p. 01).

The accumulated literature on the subject suggests that the relationship between companies and society is complex, and involves communities, employees, governments and even other companies, and therefore objectively defining the concept becomes troublesome. Although recognizing that the notion of CSR is still evolving, we have adopted in this study Aguinis' (2011) concise and encompassing definition, which views CSR as a set of "context-specific initiatives and policies, which take into account the expectations of stakeholders and the triple bottom line of economic, social and environmental performance" (p. 855).

Managerial attitudes towards CSR and level of company engagement in CSR activities vary by country. Waldman et al. (2006) have observed that managers in countries with high institutional collectivism and with low power distance traits, that is cultural values that focus on addressing longterm concerns and lessening inequity respectively, are more likely to show behaviors positively associated with CSR. Since Brazil is a country where institutional collectivism is average to low, and power distance is high (House, Hanges, Javidan, Dorfman, \& Gupta, 2004), it should come as no surprise that CSR issues in the Brazilian business environment are still not as widespread as compared to other countries. Nevertheless, pressures from interest groups and attention to such issues by the business media have increased concerns regarding corporate social performance in the country (Puppim, 2008). Therefore, since the early 2000s, some Brazilian companies began to voluntarily demonstrate their social performance through the adoption of social balance sheets or social reports, thereby disclosing economic and social information related to their initiatives in this area (Tinoco, 2008).

\section{CSR and business financial performance}

Many authors have pinpointed that companies which neglect their social responsibilities are likely to experience several negative consequences that can affect the economic value of the firm directly, when fines and pay damages or subsidies are due, and indirectly, through impact on the firm's reputation, which can ultimately weaken the brand (Brammer \& Pavelin, 2006). On the other hand, conflicting views have emerged in the literature regarding company outcomes of direct investments in CSR. Some authors argue that CSR investments represent additional costs for the business and ultimately have a negative impact on financial performance (e.g.: Margolis \& Elfenbein, 2008). Others, however, believe that CSR initiatives can positively affect a business, by improving the company's image, strengthening the loyalty of clients or favoring a positive assessment of the company's products (Aguilera, Rupp, Williams, \& Ganapathi, 2007), and therefore reap benefits in the long run.

A number of studies have investigated the relationship between corporate social responsibility and financial outcomes in both the short term and the long term (e.g. Peloza \& Shang, 2011). Systematic reviews of literature (e.g.: Orlitzky et al., 2003) have suggested that the relationship is significant and positive. However, scrutiny of many studies conducted revealed inconsistencies and raised methodological concerns, due to the great diversity of extant social and environmental performance measures, sampling limitations, lack of control over interactions between the variables under study, and obscurity in regards to direction of causality (i.e., whether CSR determines financial performance or the other way around) (Ionescu-Somers, Salzmann, \& Steger, 2005; Peloza, 2009).

The majority of quantitative studies on the topic found in the literature used data collected in the U.S. and EU, therefore little is known about companies that operate in other regions of the world, and despite the results so far generated in the field, the bulk of the literature on CSR consists of studies that 
employed level and panel analysis, which does not adequately account for the problems of endogeneity or reverse causality (Ree \& Carretta, 2006). Moreover, research has indicated that different foci of CSR initiatives (e.g.: directed towards primary stakeholders, such as employees and investors, or secondary stakeholders, such as communities and the environment) may have quite different effects on financial outcomes (Van der Laan et al., 2008). All things considered, it seems still necessary to verify how and when CSR investments are likely to affect firm performance.

\section{Internal corporate social responsibility (I-CSR)}

Most discussions in the CSR field are driven by issues inherent to external CSR (e.g., the preservation of the environment; companies' involvement in the communities where they operate), while the concept of internal CSR (I-CSR) has been relatively ignored (Aguilera et al., 2007; Aguinis \& Glavas, 2012). I-CSR refers to how firms respond to their responsibilities in regards to their employees, i.e., the work relations sphere.

Standards of internal social responsibility within firms are discussed in several international documents, such as the European Union's Green Paper (European Commission, 2001) and the United Nations' Global Compact (United Nations, n.d.). They are also dealt with detail in documents produced by entities such as the International Labor Organization (ILO, 1998), and in the information guides of the Global Reporting Initiative (GRI, 2011). The CSR literature discusses I-CSR issues at the institutional, organizational and individual level of analyses (Carroll, 2008; Puppim, 2008). Institutional I-CSR initiatives encompass the social dialogue on labor relations between corporations and other organizations, such as, unions and professional representative bodies, and address normative and regulative issues (e.g., Christmann \& Taylor, 2006). I-CSR initiatives on the organizational level focus the work context and entail broad policies that aim at improving the physical environment for several employees, such as eliminating workplace risks that might pose a threat to their health and safety, or designing jobs in ways that promote involvement and participation (e.g., Turker, 2009). I-CSR initiatives on the individual level focus on employees more directly, and address their specific needs. They range from programs that center on professional development, such as sponsoring training and professional education, to initiatives that attend to their needs beyond the workplace, such as offering pension plans and profit-sharing (e.g., Aguilera et al., 2007).

Although some internal CSR investments may reflect a concern with legal aspects and aim at reducing labor-related costs (Barnett, 2007), several I-CSR initiatives can promote positive employee attitudes and their improved performance, and therefore affect organizational effectiveness, particularly those that directly affect individual employees (Cohen, 2010; Mcwilliams, Siegel, \& Wright, 2006). Researchers have suggested that companies with a socially responsible culture have an intangible asset to attract, retain, and engage the workforce (Bhattacharya, Korschun, \& Sen, 2009). However, little is known about the outcomes of specific I-CSR investments in terms of costs and returns.

\section{Hypotheses}

Due to increased competitiveness in today's business environment, every available financial resource, either for reinvestment or shareholder returns, is valuable. The dilemma to reinvest in the company - building new manufacturing facilities, developing new products, and sponsoring human resources programs, among others - or simply returning the funds to shareholders through dividend payments is often an issue for executives in such contexts. Without the presentation of projections and return perspectives regarding the decision to invest in I-CSR, such expenditures tend to be regarded as costs rather than investments.

Notwithstanding, since the 1990's, the resource-based view of the firm (RBV) (Barney, 1991; Wernerfelt, 1984) has been widely used to explain how organizations achieve competitive advantage through unique assets they detain, such as capital, brand, skilled personnel and knowledge (Wernerfelt, 1984). According to this perspective, superior organizational performance and competitive advantage is accomplished when companies own or control assets that are rare and valuable, particularly when they 
are difficult to be imitated or transferred to other organizations. Intangible assets, such as competences and capabilities, seem to be especially relevant to the development of competitive advantage (Barney, 2001). Amit and Schoemaker (1993) further emphasize that capabilities are grounded on processes that mainly consist of activities developed, carried and exchanged by the firm's human capital, that is, by the company's employees at all hierarchical levels.

Grounded on the resource-based perspective, we suggest that attracting and retaining human capital (Ployhart, 2004) can offer a strategic advantage for companies (Ployhart \& Moliterno, 2011). Studies have shown that human resources management policies, many of which are now listed as I-CSR standards, can foster performance and bring about improved results at the organizational level (Aguilera et al., 2007; Cooper \& Wagman, 2009; Van der Laan et al., 2008). I-CSR initiatives that focus on individual employees are likely to boost human capital through three mechanisms: (a) by attracting more qualified workers; (b) through on-going expansion of employee skills; and (c) through the retention and engagement of the workforce.

Researchers have suggested that internal social responsibility initiatives can favor the company's reputation and promote their positive image as an employer (Brammer \& Pavelin, 2006), thereby increasing the company's capacity to attract the best talent available in labor markets (Kim \& Park, 2011). This can be strategic for companies, since human capital acquisition risks pose threats to productivity, as well as turnover and replacement costs (Brymer, Molloy, \& Gilbert, 2014), particularly in industries in which competition to hire professionals and specialized technical workers is tougher (Somaya, Williamson, \& Lorinkova, 2008). It also becomes more critical as new generations enter the market with inflated expectations regarding work-life balance, personal development programs and career growth opportunities (Deal, Altman, \& Rogelberg, 2010).

I-CSR can also have effects on the performance of workers in a more direct way, by promoting greater levels of efficiency through learning and development of new skills (Barney, 1991; Lee \& Bruvold, 2003). Research has evidenced a positive relationship between the number of employees who received training and the performance of companies, especially in the services sector (Van de Wiele, 2010). Nowadays, providing on-going training for workers is no longer an option, but rather a necessity, insofar as a company's competitiveness is concerned. Investment in training and education can foster immediate, non-financial gains such as greater product quality and increased operational efficiency (Cegarra-Navarro, Reverte, Gomez-Melero, \& Wensley, 2016; Chen \& Huang, 2009), which over time should have a positive impact on company results. Corporate social responsibility practices, including focus on employee education and development, have been associated with positive organizational outcomes such as performance (Agan, Kuzey, Acar, \& Acikgoz, 2016; Ferraz \& Gallardo-Vazquez, 2016).

Investment in I-CSR may also encourage competent employees to stay with the company (Cooper \& Wagman, 2009), enabling the retention of knowledge that is relevant to the business and reducing turnover costs (Kacmar, Andrews, Van Rooy, Steilberg, \& Cerrone, 2006). Research has unveiled a positive relationship between corporate social responsibility and workers' commitment to the companies they work for (Brammer, Pavelin, \& Porter, 2009), either through the strengthening of the emotional ties they have to these organizations, or through an increased sense of duty and obligation to their companies (Eisenberg, Kilduff, Burleigh, \& Wilson, 2001). Other studies have shown that when employees believe that the company which they work for is committed to them, guaranteeing their rights as workers, protecting their health and safety and investing in their professional development, their emotional ties and desire to remain at this company are positively influenced (Brammer, Millington, \& Rayton, 2007; Jones, 2010).

Therefore, although the human element is not explicitly included in the companies' balance sheets, at least part of their corporate value is derived from the people that conduct their operations at all levels, that is, from their human capital. In his seminal survey, Huselid (1995) observed that strategic human resource management practices, such as investments in selective hiring, employee development and job security, were related to reduced turnover and the increased productivity of workers. These are all practices and policies that reflect company concern for employees, and the amount of specific 
investments on them indicates how far organizations will actually go taking on such internal social responsibilities. Both, theory and research on I-CSR (e.g., Aguilera et al., 2007; Cooper \& Wagman, 2009; Van der Laan et al., 2008) have strongly supported the proposition that companies that make more substantial investments on employees are more likely to attract, engage and retain human capital, and therefore improve their performance (Aguinis \& Glavas, 2012). Thus, we propose that:

H1: Companies' expenditures on I-CSR will be positively associated with their financial results (net revenue) in the years following such outlays.

Resources such as knowledge and competencies have been systematically related to company performance, leading to better processes, results, and innovations (e.g.: Cegarra-Navarro et al., 2016; Inkinen, 2016). Employee development and managerial competence development are relevant I-CSR investments that can impact company operations (Agan et al., 2016; Chen \& Huang, 2009; Ferraz \& Gallardo-Vazquez, 2016), particularly in transitional economies (Lau, 2011; Rettab, Brik, \& Mellah, 2009), where access to technical and higher education is often limited and costly (Dourado, 2007). Therefore, we propose that:

H1a: I-CSR expenditures on employee education will be positively associated with financial results (net revenue) in the years following such outlays.

Employee health has been systematically related to performance in the organizational context (Ford, Cerasoli, Higgins, \& Decesare, 2011). In addition, job satisfaction, which is a proxy indicator for employee well-being in stress research, has been also associated with individual employee performance (Judge \& Bono, 2011). Given the importance of health care for the overall comfort of employees, the limited and often precarious provision of these public services in Brazil, and the costly access to private alternatives (Neri \& Soares, 2002), we further specify the following hypothesis:

H1b: I-CSR expenditures on employee health will be positively associated with financial results (net revenue) in the years following such outlays.

As mentioned previously, I-CSR is considered a factor in the attraction of talented workers (Kim \& Park, 2011; Cooper \& Wagman, 2009; Van der Laan et al., 2008), particularly compensation schemes (Chapman, Uggerslev, Carroll, Piasentin, \& Jones, 2005). There is also evidence in the literature of the motivational power of employee incentives that tie employee compensation schemes to company results in the short and long run (e.g.: Rynes, Gerhart, \& Parks, 2005). In particular, profit sharing has been systematically associated with employee performance (e.g.: Han, Bartol, \& Kim, 2015). Therefore, we further specify the following hypothesis:

H1c: I-CSR expenditures on profit sharing will be positively associated with financial results (net revenue) in the years following such outlays.

Finally, research on I-CSR has also emphasized the impact of organizational initiatives on affective and instrumental commitment (e.g., Brammer et al., 2009 Kacmar et al., 2006; Rettab et al., 2009). In particular, benefits such as pension plans are known to promote organizational commitment and employee retention (Dulebohn, Molloy, Pichler, \& Murray, 2009). Furthermore, the costs associated with employee turnover are well known to companies (Mitchell, Holtom, Lee, Sablynski, \& Erez, 2001), while tangible (e.g.: salary and benefits) and intangible (e.g.: training and development) incentives have been widely associated with lower voluntary turnover (Heavey, Holwerda, \& Hausknecht, 2013). Therefore, we propose the following hypothesis:

H1d: I-CSR expenditures on pension plans will be positively associated with financial results (net revenue) in the years following such outlays. 


\section{Methodology}

\section{Data and sample}

Aside from the absence of any legal obligation of Brazilian companies to provide information regarding their social performance, a lack of common indicators also complicates the accurate measurement of corporate responsibility in the country. In spite of this, the Brazilian Institute for Social and Economic Analysis (Instituto Brasileiro de Análises Sociais e Econômicas [IBASE]) in conjunction with the Securities and Exchange Commission of Brazil (Comissão de Valores Mobiliários [CVM]) have developed a model widely used by companies to report their CSR disbursements during the 2000s, the Social Balance Sheet (Reis \& Medeiros, 2007). This is a relatively simple form, with short and objective questions regarding yearly financial expenditures on diverse CSR domains, including I-CSR. The data used in this analysis was retrieved directly from the IBASE's database, where companies in the country have filled their social balance sheets. We were able to retrieve from such reports specific financial information provided by companies regarding personnel outlays on food, contributions, pension plans, healthcare, safety, education, cultural initiatives, training, child care and profit-sharing.

The initial sample contained 364 publicly traded and privately held companies. Companies not listed on the stock exchange were removed from the sample, as well as those without at least four years of available information in the database. This was done in order to limit the degree of imbalance of the panel and to allow an analysis of the independent variables with lags of two periods. The period from 2001 to 2007 was chosen in part because of a lack of data available for years prior to 2001 and post 2007, but also to avoid the internet bubble crisis of 2000 and the housing crisis of 2008. The final sample analyzed in this study contained 79 publicly listed companies.

\section{Analysis procedures}

The nature of the phenomenon investigated in this study makes the analysis susceptible to endogeneity, because of the difficulty one encounters in establishing the direction of causality. Although, on the one hand, the level of internal investment may improve a company's results to some degree, the possibility exists, on the other hand, that companies that obtain better financial results will have a greater propensity to spend more internally, through the creation of the so-called free cash flow (Jensen, 1986). Because of the potential endogeneity, estimating the regression directly via OLS can result in coefficients that are biased (Antonakis, Bendahan, Jacquart, \& Lalive, 2010; Wooldridge, 2002).

In order to avoid this bias, we applied the following structural model:

$$
\left\{\begin{array}{l}
\frac{\text { Net Revenue }}{\text { Number of Employees }_{i t}}=\mathbf{c}+\sum_{\mathbf{c}=1}^{4} \boldsymbol{\theta}_{\mathbf{c}} * \mathbf{X}_{\mathrm{cit}}+\boldsymbol{\theta}_{5} * \text { Payroll }+\mathbf{u}_{\mathrm{it}} \\
\sum_{\mathbf{c}=\mathbf{1}}^{\mathbf{4}} \mathbf{X}_{\mathrm{cit}}=\boldsymbol{\sigma}+\gamma_{1} * \frac{\text { Net Revenue }}{\text { Number of Employees }_{\mathrm{it}}}+\gamma_{2} * \text { Payroll }+\mathbf{e}_{\mathrm{it}}
\end{array}\right.
$$

$$
\text { We used revenue by employee ( } \frac{\text { Net Revenue }}{\text { Number of Employees }_{\text {it }}} \text { ) to represent the results of company } i \text { in year }
$$

$t$. This was done since revenue is a performance indicator that captures improvements in operational performance, such as increases in sales or cost reductions, which are highly influenced by a company's human capital. Net revenue was divided by the number of employees to reflect the average employee contribution and to avoid biases introduced by company's headcount on revenue. Net profit was not used to assess performance in the previous equations, since that indicator is influenced by exogenous variables such as tax payments and other financial results less directly affected by a company's workforce. Although measures such as ROA and ROI are also indicators that consider company revenue, 
we refrained to using such financial measures because they could also be biased by pre-existing company differences in regards to equity and assets unrelated to employees. At last, we chose not to use indicators related to these companies stock's market, such as ratios as the P/E (Price-to-Earnings) or the stock's returns, since they are highly affected by market fluctuations and have little to do with the performance of the majority of employees (unless they act as insiders, which is not the focus of our study).

We deemed it not necessary to control for sectors in the analyses, since Brazilian economy (especially public listed companies) is focused in capital intensive and commodities related businesses. The sector control would be needed in other developed countries, such as USA, which have a large number of public traded companies with high revenue for a relative low number of employees (such as the technology sector).

In the equations, $\mathbf{X}_{\mathbf{c i t}}$ represents I-CSR spending dimension, $\mathbf{c}$ (healthcare, education, profitsharing and pension plans), per employee, for company $\mathbf{i}$, in year $\mathbf{t}$. Although there are other expenditures focusing on employees in the IBASE database, our estimation initially focused on the aggregate effect of those of interest in this study, and, in the subsequent analysis, on their unique effects. Finally, the company's payroll is used as a proxy to control for market size and also to control for company stock of talent. The random errors are represented by $\mathbf{u}_{\mathbf{i t}}$ and $\mathbf{e}_{\mathbf{i t}}$.

The equation of interest is the first of the system, that is, the one that measures whether spending on I-CSR has an effect on the net revenue of the company. The methodology for resolving the problem of simultaneity involves using instrumental variables and estimating the coefficients by Two-Stage Least Squares (2SLS). For this purpose, first, exogenous variables that substantially correlate with the independent variable one wants to instrumentalize and that are independent of the regression error must be found (Antonakis et al., 2010; Wooldridge, 2002). Thus, we had to identify a variable that correlates with the company's I-CSR investments, but not with error $u_{i t}$, which accounts for other factors that influence net revenue and that are not specified in the model.

Best practices of governance invariably involve decision making that takes into account all of the company's stakeholders, and not just the controlling shareholders (Akerstrom, 2009). Because of this, an association between a company's level of corporate governance and investments in CSR can be expected (see also, Graaf \& Stoelhorst, 2009). On the other hand, while some researchers observed a relationship between corporate governance and financial results such as stock price/company value in Brazil (Silveira, 2004), others did not observe any direct effects (Aguiar, Corrar, \& Batistella, 2004). As far as we know, no previous study has observed any direct effect of company governance and revenue in Brazil. Since net revenue reflects a company's operational performance, it shouldn't be directly affected by governance, but through specific initiatives, practices and policies fostered by it (Aguinis \& Glavas, 2012). So, corporate governance was selected to instrumentalize the aggregate I-CSR investments and test $\mathrm{H} 1$.

In Brazil, companies listed on the São Paulo Stock Exchange (BOVESPA) are classified in different categories according to their level of commitment to best practices of corporate governance: N1, N2, and New Market. These classifications represent the company level of adherence to increasingly stricter practices of corporate governance, therefore, four categories were coded: (a) Traditional Market (lower level of governance); (b) N1; (c) N2; and (d) New Market (higher level of governance - NM). Three dummy variables were then created to be used as instruments for the I-CSR spending allocations, one for each special listing: N1, N2 and NM. For example, Vale, a large Brazilian mining company, was listed on the Traditional Market up until 2003, when the organization moved to Level 1. Thus, Vale's N1 dummy was given a value of 0 for the years 2001 and 2002, and 1 for the period between 2003 and 2007, while variables N2 and NM were set to zero in all years between 2001 and 2007. It is worth noting that the exigencies imposed to grant each governance level vary in terms of the requirements to acquire a new, upgraded rating. For example, there are seven standards a company must comply to in order to move from the Traditional Market to N1, and only one to move from N2 to NM.

Although using the corporate governance variable allowed us to instrumentalize the aggregate ICSR investments, it was not possible to use that same variable to estimate the unique impact of each of 
the four dimension of I-CSR expenditure of interest in a 2SLS scheme, due to overidentification issues. Therefore, we searched into our database to identify at least one ideal instrument among the variables available to control for endogeneity in the follow-up analyses to test H1a, H1b, H1c and H1d. To better address which variables in the dataset would be best fitted to be used as instrumental variables, we estimated correlations between them, our predictors of interest and net revenue. Variables (expenditures) that had a high correlation with our independent variables and which had nonsignificant correlations with net revenue of the companies were used. Therefore, investments on education, health care, pension plans and profit sharing were respectively instrumentalized with company expenditures on training, safety, food and contributions.

After defining how to measure the independent and dependent variables and identifying suitable instruments, we run the first step of the 2SLS analysis by estimating the equations that instrumentalize the I-CSR dimensions of interest. The following model estimated the aggregate I-CSR investments:

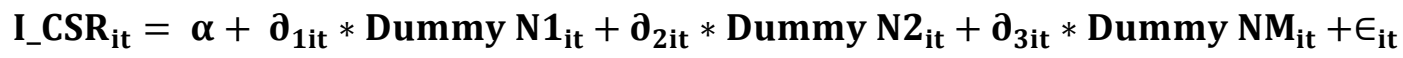

In the equation (2), I_CSR $\mathbf{C S}_{\mathbf{i t}}$ represents the aggregate I-CSR expenditures on healthcare, education profit sharing and pension plans, for company $i$ in year $t$, Dummy $\mathbf{N} \mathbf{1}_{\text {it }}$, Dummy $\mathbf{N} \mathbf{2}_{\text {it }}$ and Dummy $\mathbf{N M}_{\mathbf{i t}}$ represent each corporate governance category; and $\epsilon_{\mathbf{i t}}$ is the random error.

The second stage of the 2SLS method involves estimating the equation of interest using the instrumentalized variables to obtain unbiased and consistent estimators. Therefore, following model was estimated:

$$
\frac{\text { Net Revenue }}{\text { Number of Employees }_{\text {it }}}=\mathbf{A}+\mathbf{B}_{1} * \mathbf{I}_{-} \mathbf{C S R}_{\text {instr }_{\text {it }}}+\mathbf{B}_{2} * \text { Payroll }+\mathbf{U}_{\mathrm{it}}
$$

In the equation (3), $\mathbf{I}_{-} \mathbf{C S R}_{\mathbf{i n s t r}_{\mathbf{i t}}}$ is the intrumentalized variable corresponding to the aggregate ICSR expenditures for company $\mathbf{i}$, in year $\mathbf{t}$.

We followed the same procedure to analyze the unique effects of the four I-CSR investments of interest. The following model estimated each specific dimension of the I-CSR of interest in our study:

$$
\mathrm{X}_{\mathrm{cit}}=\alpha+\delta_{1 \mathrm{it}} * \mathbf{V}_{\mathrm{it}}+\boldsymbol{\rho}_{\mathrm{it}}
$$

In the equation (4), $\mathbf{X}_{\mathbf{c i t}}$ represents the I-CSR expenditures of type $\mathbf{c}$ (health, education, profit sharing and pension plans) for company $\mathbf{i}$ in year $\mathbf{t}$; $\mathbf{v}_{\mathbf{i t}}$ are the respective instrumental variables; and $\boldsymbol{\rho}_{\mathbf{i t}}$ is the random error.

In the second stage of the 2SLS, we estimated the equation of interest using the instrumentalized variables to obtain consistent estimators. Therefore, the following model was estimated:

$$
\frac{\text { Net Revenue }}{\text { Number of Employees }_{i t}}=\alpha+\sum_{\mathbf{c}=1}^{4} \boldsymbol{\beta}_{\mathrm{c}} * \mathbf{X}_{\mathrm{instr}_{\mathrm{cit}}}+\boldsymbol{\beta}_{5} * \text { Payroll }+\mathbf{u}_{\mathrm{it}}
$$

In the equation (5), $\mathbf{X}_{\text {instr }}$ cit are the instrumentalized variables corresponding to each I-CSR dimension of type $c$ for company $\mathbf{i}$, in year $\mathbf{t}$. By following this procedure, the regression coefficients estimated the effect of each of the four I-CSR dimensions on companies' net revenues. To take into account any potential delayed effects of spending on I-CSR outlays, the dependent variable was also regressed against the lags of the independent variables for t-1 and $\mathbf{t}-\mathbf{2}$.

\section{Results}

The descriptive statistics for variables $\frac{\text { Net Revenue }}{\text { Number of Employees }}, \frac{\text { Net Revenue }}{\text { Payroll }}$, and $\mathbf{X}_{\mathbf{c}}$ are shown in Table 1. 
Table 1

Descriptive Statistics (in R\$ Thousands)

\begin{tabular}{lcccccccc}
\hline Variable & Mean & Median & Min. & Max. & Std. Dev. & CV & Est. Bias & Kurtosis \\
\hline Child care & 0.04 & 0.01 & 0.00 & 1.80 & 0.13 & 3.11 & 8.56 & 95.10 \\
Contributions & 3.39 & 2.32 & 0.00 & 119.79 & 6.49 & 1.91 & 14.52 & 250.39 \\
Cultural initiatives & 0.12 & 0.00 & 0.00 & 13.02 & 1.16 & 9.33 & 10.63 & 111.80 \\
Education & 0.07 & 0.04 & 0.00 & 2.08 & 0.17 & 2.28 & 8.40 & 85.54 \\
Food & 0.78 & 0.40 & 0.01 & 15.31 & 1.26 & 1.62 & 6.35 & 58.28 \\
Healthcare & 0.57 & 0.40 & 0.01 & 9.51 & 0.64 & 1.13 & 7.36 & 91.40 \\
Pension plans & 0.83 & 0.30 & -1.24 & 46.22 & 2.70 & 3.26 & 12.78 & 202.27 \\
Profit sharing & 0.85 & 0.64 & 0.00 & 7.64 & 1.02 & 1.20 & 3.56 & 16.24 \\
Safety & 0.16 & 0.06 & 0.00 & 10.11 & 0.57 & 3.50 & 15.96 & 276.73 \\
Training & 0.24 & 0.11 & 0.00 & 13.65 & 0.88 & 3.71 & 12.19 & 165.25 \\
Others & 0.30 & 0.20 & 0.00 & 7.36 & 0.46 & 1.54 & 9.29 & 133.47 \\
Net Rev./ N ${ }^{\circ}$ Employees & $1,780.70$ & 708.20 & 24.70 & 130260 & $7,860.30$ & 4.41 & 12.72 & 186.32 \\
Payroll & 817500 & 212480 & 1619 & 8625200 & $1,707.00$ & 2.09 & 3.11 & 8.91 \\
Net Rev./ Payroll & 17.15 & 10.66 & 0.20 & 307.58 & 30.42 & 1.77 & 6.42 & 47.54 \\
\hline
\end{tabular}

In the first stage of the 2SLS procedure, regression analyses (models B and D) were carried out on aggregate and each allocation of internal I-CSR, using the instrumental variables. The results are shown in Table 2.

Table 2

Regressions: Estimation of I-CSR - Aggregate and Specific Dimensions (Pension Plans, Healthcare, Education and Profit Sharing), applying Instrumental Variables

\begin{tabular}{|c|c|c|c|}
\hline & & & \multirow{2}{*}{$\overline{\text { I-CSR (aggregate) }}$} \\
\hline & & & \\
\hline const & & & $1.282 * * *$ \\
\hline Dummy_N1 & & & $1.309^{* * *}$ \\
\hline Dummy_N2 & & & $0.890^{*}$ \\
\hline Dummy_NM & & & 0.456 \\
\hline & Pension Plans & & Healthcare \\
\hline const & $0.461 *$ & Const & $2.78^{* * * *}$ \\
\hline Food & $0.843 * * *$ & Safety & $0.891 * * *$ \\
\hline & Education & & Profit Sharing \\
\hline const & 0.714 & Const & 0.309 \\
\hline Training & $0.801 * * *$ & Contributions & $0.876 * * *$ \\
\hline
\end{tabular}

Note. $*$ Probability Note: $* \mathrm{p}<0.10, * * \mathrm{p}<0.05, * * * \mathrm{p}<=0.01$.

As explained above, the estimated coefficients were used to obtain the instrumentalized predictor variables. For example, the variable healthcare was instrumentalized based on the following expression: 


$$
\text { Healthcare }_{\text {instr }_{i t}}=2.78+0.891 * \text { Safety }_{\text {it }}
$$

With all the variables instrumentalized, we estimated the equations of interest ( 3 and 5), testing the hypotheses mentioned earlier. Table 3 presents the results obtained for the aggregate expenditures, with $\frac{\text { Net Revenue }}{\text { Number of Employees }}$ as the dependent variable. Table 4 opens the results based on the follow-up analysis, considering each of the four dimensions of interest separately. In both models, variables were regressed against the selected contemporary I-CSR expenses, as well as against the expenses with lags of $\mathbf{t}-\mathbf{1}$ and $\mathbf{t}-\mathbf{2}$ years.

Table 3

Regression: Temporal Relations with Net Revenue per Employee by Aggregate I-CSR Investments (Considering: Healthcare, Education, Profit Sharing and Pension Plans)

\begin{tabular}{llll}
\hline VarDep $=$ Net Rev./ $\mathrm{N}^{\circ}$ Employees & Contemporary & $\mathrm{t}-1$ & $\mathrm{t}-2$ \\
\hline Const & -752.25 & -567.91 & -275.38 \\
$\mathrm{I}-\mathrm{CSR}$ (aggregate) & $19852.03^{* * *}$ & $23913.67^{* * *}$ & $12189.27^{* *}$ \\
Payroll & $0.0002^{* *}$ & 0.0001 & 0.0004 \\
\hline $\mathrm{R}^{2}$ & 0.4373 & 0.4829 & 0.2962 \\
\hline
\end{tabular}

Note. $*$ Probability Note: $* \mathrm{p}<0.10, * * \mathrm{p}<0.05, * * * \mathrm{p}<=0.01$.

Table 4

Regression: Temporal Relations with Net Revenue per Employee by Specific I-CSR Dimension (Healthcare, Education, Profit Sharing and Pension Plans)

\begin{tabular}{llll}
\hline VarDep $=$ Net Rev./ $\mathrm{N}^{\circ}$ Employees & Contemporary & $\mathrm{t}-1$ & $\mathrm{t}-2$ \\
\hline Const & 8240.12 & 7291.72 & 4281.09 \\
Pension Plans_Instr & $815.81^{* *}$ & $856.19^{* *}$ & $518.65^{*}$ \\
Healthcare_Instr & $5182.85^{*}$ & 2127.28 & $8632.79^{* *}$ \\
Education_Instr & $18172.08^{* * *}$ & $14524.01^{* * *}$ & 5612.11 \\
Profit Sharing_Instr & 131.15 & $921.13^{*}$ & $991.44^{*}$ \\
Payroll & $0.0001^{*}$ & $0.0003^{* *}$ & 0.0002 \\
$\mathrm{R}^{2}$ & 0.5722 & 0.5204 & 0.4101 \\
\hline
\end{tabular}

Note. * Probability Note: $* \mathrm{p}<0.10, * * \mathrm{p}<0.05, * * * \mathrm{p}<=0.01$

Based on the observed results, one can conclude that publicly traded companies in the Brazilian stock market that made more substantial investments on I-CSR generated additional revenue, and the effects of these investments spilled over at least two years after they were made. These results corroborated H1.

Moreover, as can be seen in Table 4, investments on all four specific I-CSR dimensions of interest in this study, i.e., healthcare, education, profit sharing and pension plans, were positively associated with financial results. Investments on health care were associated with revenue contemporarily and two years after such outlays, thus confirming H1a. Investments on formal education, which intends to increase employees' technical and managerial skills and abilities, were associated with revenue contemporarily and one year after such outlays, thus confirming H1b. Investments on profit sharing were associated with revenue in the long run, i.e., one and two years after such outlays, thus confirming H1c. Finally, investments on private pension plans, such as the counterpart contribution by companies 
up to a certain percentage of an employee's gross salary, lead to an increase in company revenues contemporarily, as well as one and two years following such outlays, thus confirming H1d.

\section{Discussion and Conclusion}

The results of our analyses indicate that investments in internal social responsibility, as measured by monetary indicators, are associated with the financial performance of companies listed in the Brazilian stock exchange in the years following such outlays, adding weight to the idea that internal social responsibility, i.e., initiatives that focus on company's employees, can positively affect returns. This result is in line with the preliminary observations of meta-analytical studies, such as those of Orlitzky, Schmidt and Rynes (2003), which suggest that there is a positive relationship between CSR and the financial performance of firms, and with propositions that internal social responsibility can benefit companies (Cohen, 2010; Turker, 2009). Our findings indicate, more specifically, that investments that focused on employee education, healthcare, profit sharing and pension plans, can all drive such effects in the medium and long terms.

Our research offers three original contributions to the field of CSR. Firstly, the study considers an allocation of CSR that has only been touched upon by previous works - internal CSR, or I-CSR (Aguinis \& Glavas, 2012; Weber, 2008). We also present a framework grounded in strategy theory (i.e., RBV) to explain why that sphere of corporate citizenship has a strong potential to directly affect the performance of companies, therefore offering a sound theoretical rationale that adds insight to the field. Furthermore, besides analyzing the effects of overall investments in I-CSR, we examined the impact of specific dimensions, which allowed us to pinpoint which outlays or expenditures had an influence on future corporate performance.

Secondly, the methodology used in this study has helped minimizing the problems of endogeneity and reverse causality (Antonakis et al., 2010; Ree \& Carreta, 2006; Wooldridge, 2002) so often observed in analyses of this kind (c.f., Peloza, 2009). To the best of our knowledge, no previous studies applied the 2SLS estimation to reduce biases and separately analyzed the implications of a set of I-CSR indicators on business performance over the short and long terms.

Finally, this research contributes to extend knowledge about the impact of CSR on company performance beyond the US-EU, in the context of an emerging economy with a diverse socioeconomic and cultural context, an initiative that has been called for in the literature (e.g., Lau, 2011; Waldman et al., 2006). One can thus conclude that companies traded in the Brazilian stock market that invested on pension plans heaped strong and enduring benefits in the short, medium and long terms; those that invested on employee formal education heaped benefits as soon as the investments were made and in the medium term; and those that made stronger investments in healthcare and profit sharing heaped financial gains in the long term, within up to two years after such investments had been made.

As previously noted, a possibility exists that internal CSR investments are related to performance to an even greater extent than external and environmental investments, since the latter would affect business operations and effectiveness through more indirect mechanisms, such as the improvement of a company's good image and reputation, whose effect is more difficult to control and to predict (Miles \& Covin, 2000). On the other hand, I-CSR affects stakeholders that are responsible for running daily business operations, and therefore represent investments in the companies' human capital. The results of this study, therefore, reinforce the importance of I-CSR not only from the standpoint of companies' moral and legal obligations, but also in view of its impact on organizational performance.

This study did suffer certain limitations, which should be considered. The investigation focused on a sample of openly traded, listed companies, which are fairly differentiated from other businesses. Although the results are valid for this kind of company operating in Brazil during the period analyzed, one cannot generalize the findings to include closed private companies or smaller enterprises. 
Furthermore, the study looked at a relatively limited set of I-CSR indicators, constrained to those incorporated in the IBASE balance sheet, leaving aside new dimensions presently discussed in this field (Cegarra-Navarro et al., 2016). One should also keep in mind that we presumed that the information provided by companies in their balance sheets was true and accurate, although that cannot be taken for granted.

Future research should look beyond the relationships here addressed, to include other areas of internal investment that were not contemplated in the IBASE's social balance sheets, or test these same relationships in different groups of companies. However, reliable I-CSR measures of additional dimensions of I-CSR, as well as valid and appropriate instruments used by private un-listed companies to report such expenditures are hard to find, which poses a challenge for researchers interested in carrying out successful studies of this kind. Nevertheless, scholars should continue to research CSR in general, envisioning new and reliable mechanisms to measure company's investments in diverse domains, in order to better understand the mechanisms through which corporate citizenship influence company performance, as well as contextual factors that may intensify or restrict such effects.

Lastly, the growth in market competitiveness we have witnessed lately has brought companies to a point where every single resource available is of vital importance, and any initiatives that can help establishing priorities for reinvesting may be beneficial to support more effective business decisions. Therefore, the results of this study have practical implications and reinforce the idea that spending on internal social responsibility, on employees, seems to pay off. Our findings should encourage firms to recognize such outlays as investments in human capital that can lead to greater performance in the short and long run, particularly in countries such as Brazil, where public health and education, as well as social security systems, tend to be much less effective. Such initiatives can benefit both firms and employees, but also society as a whole, since they will improve the well-being, the overall quality of life and the technical advancement of a substantial number of workers.

\section{References}

Agan, Y., Kuzey, C., Acar, M., \& Acikgoz, A. (2016). The relationships between corporate social responsibility, environmental supplier development, and firm performance. Journal of Cleaner Production, 112(3), 1872-1881. http://dx.doi.org/10.1016/j.jclepro.2014.08.090

Aguiar, A. B., Corrar, L. J., \& Batistella, F. D. (2004). Adoção de práticas de governança corporativa e o comportamento das ações na Bovespa: evidências empíricas. Revista de Administração da USP, 39(4), 338-347. Retrieved from http://rausp.usp.br/wp-content/uploads/files/V3904338a347.pdf

Aguilera, R. V., Rupp, D. E., Williams, C. A., \& Ganapathi, J. (2007). Putting the S back in corporate social responsibility: a multilevel theory of social change in organizations. Academy of Management Review, 32(3), 836-863. http://dx.doi.org/10.5465/AMR.2007.25275678

Aguinis, H. (2011). Organizational responsibility: doing good and doing well. In S. Zedeck (Ed.), APA handbook of industrial and organizational psychology (Vol. 3, pp. 855-879). Washington, DC: American Psychological Association.

Aguinis, H., \& Glavas, A. (2012). What we know and don't know about corporate social responsibility: a review and research agenda. Journal of Management, 38(4), 932-968. http://dx.doi.org/10.1177/0149206311436079

Akerstrom, A. (2009). Corporate governance and social responsibility. Munich: GRIN Verlag.

Amit, R., \& Schoemaker, P. J. (1993). Strategic assets and organizational rent. Strategic Management Journal, 14(1), 33-46. http://dx.doi.org/10.1002/smj.4250140105 
Antonakis, J., Bendahan, S., Jacquart, P., \& Lalive, R. (2010). On making causal claims: a review and recommendations. The Leadership Quarterly, 21(6), 1086-1120. http://dx.doi.org/10.1016/j.leaqua.2010.10.010

Barnett, M. L. (2007). Stakeholder influence capacity and the variability of financial returns to corporate social responsibility. Academy of Management Review, 32(3), 794-816. http://dx.doi.org/10.5465/AMR.2007.25275520

Barney, J. (1991). Firm resources and sustained competitive advantage. Journal of Management, 17(1), 99-120. http://dx.doi.org/10.1177/014920639101700108

Barney, J. (2001). Resource-based theories of competitive advantage: a ten-year retrospective on the resource-based view. Journal of Management, 27(6), 643-650. http://dx.doi.org/ $10.1177 / 014920630102700602$

Bhattacharya, C., Korschun, D., \& Sen, S. (2009). Strengthening stakeholder-company relationships through mutually beneficial corporate social responsibility initiatives. Journal of Business Ethics, 85(2), 257-272. http://dx.doi.org/10.1007/s10551-008-9730-3

Brammer, S., Brooks, C., \& Pavelin, S. (2006). Corporate social performance and stock returns: UK evidence from disaggregate measures. Financial Management, 35(3), 97-116. http://dx.doi.org/10.1111/j.1755-053X.2006.tb00149.x

Brammer, S., Millington, A., \& Rayton, B. (2007). The contribution of corporate social responsibility to organisational commitment. International Journal of Human Resource Management, 18(10), 1701-1719. http://dx.doi.org/10.1080/09585190701570866

Brammer, S., \& Pavelin, S. (2006). Corporate reputation and social performance: the importance of fit. Journal of Management Studies, 43(3), 435-455. http://dx.doi.org/10.1111/j.14676486.2006.00597.x

Brammer, S., Pavelin, S., \& Porter, L. A. (2009). Corporate charitable giving, multinational companies and countries of concern. Journal of Management Studies, 46(4), 575-596. http://dx.doi.org/10.1111/j.1467-6486.2008.00827.x

Brymer, R., Molloy, J., \& Gilbert, B. (2014). Human capital pipelines: competitive implications of repeated interorganizational hiring. Journal of Management, 40(2), 483-508. http://dx.doi.org/10.1177/0149206313516797

Campbell, J. L. (2007). Why would corporations behave in socially responsible ways? An institutional theory of corporate social responsibility. Academy of Management Review, 32(3), 946-967. http://dx.doi.org/10.5465/AMR.2007.25275684

Carroll, A. B. (2008). A history of corporate social responsibility: concepts and practices. In A. Crane, A. McWilliams, D. Matten, J. Moon, \& D. S. Siegel (Eds.), The Oxford handbook of corporate social responsibility (pp. 19-46). New York: Oxford University Press.

Cegarra-Navarro, J. G., Reverte, C., Gomez-Melero, E., \& Wensley, A. K. P. (2016). Linking social and economic responsibilities with financial performance: the role of innovation. European Management Journal, 34(5), 530-539. http://dx.doi.org/10.1016/j.emj.2016.02.006

Chapman, D. S., Uggerslev, K. L., Carroll, S. A., Piasentin, K. A., \& Jones, D. A. (2005). Applicant attraction to organizations and job choice: a meta-analytic review of the correlates of recruiting outcomes. Journal of Applied Psychology, 90(5), 928-944. http://dx.doi.org/10.1037/00219010.90.5.928 
Chen, C. J., \& Huang, J. W. (2009). Strategic human resource practices and innovation performance: The mediating role of knowledge management capacity. Journal of Business Research, 62(1), 104-114. http://dx.doi.org/10.1016/j.jbusres.2007.11.016

Christmann, P., \& Taylor, G. (2006). Firm self-regulation through international certifiable standards: Determinants of symbolic versus substantive implementation. Journal of International Business Studies, 37(6), 863-878. http://dx.doi.org/10.1057/palgrave.jibs.8400231

Cohen, E. (2010). CSR for HR: a necessary partnership for advancing responsible business practices. Sheffield: Greenleaf Publishing.

Cooper, S., \& Wagman, G. (2009). Corporate social responsibility: a study of progression to the next level. Journal of Business \& Economics Research, 7(5), 97-102. http://dx.doi.org/10.19030/jber.v7i5.2296

Deal, J. J., Altman, D. G., \& Rogelberg, S. G. (2010). Millennials at work: what we know and what we need to do (if anything). Journal of Business and Psychology, 25(2), 191-199. http://dx.doi.org/10.1007/s10869-010-9177-2

Dourado, L. F. (2007). Políticas e gestão da educação básica no Brasil: limites e perspectivas. Educação \& Sociedade, 28(100), 921-946. http://dx.doi.org/10.1590/S0101-73302007000300014

Dulebohn, J. H., Molloy, J. C., Pichler, S. M., \& Murray, B. (2009). Employee benefits: literature review and emerging issues. Human Resource Management Review, 19(2), 86-103. http://dx.doi.org/10.1016/j.hrmr.2008.10.001

Eisenberg, B., Kilduff, C., Burleigh, S., \& Wilson, K. (2001). The role of the value proposition and employment branding in retaining top talent, society for human resource management. Alexandria, VA: Society for Human Resource Management.

European Commission. (2001, July 18). Green paper: promoting a European framework for corporate social responsibility. Retrieved from http://europa.eu/rapid/press-release_DOC-01-9_en.pdf

Ferraz, F. A., \& Gallardo-Vazquez, D. (2016). Measurement tool to assess the relationship between corporate social responsibility, training practices and business performance. Journal of Cleaner Production, 129(15), 659-672. http://dx.doi.org/10.1016/j.jclepro.2016.03.104

Ford, M. T., Cerasoli, C. P., Higgins, J. A., \& Decesare, A. L. (2011). Relationships between psychological, physical, and behavioural health and work performance: a review and metaanalysis. Work and Stress, 25(3), 185-204. http://dx.doi.org/10.1080/02678373.2011.609035

Global Reporting Initiative. (2011). Sustainability reporting guidelines. Retrieved from https://www.globalreporting.org/resourcelibrary/G3.1-Guidelines-Incl-Technical-Protocol.pdf

Graaf, F. J. de, \& Stoelhorst, J. W. (2009). The role of governance in corporate social responsibility: lessons from Dutch finance. Business \& Society, 52(2), 282-317. http://dx.doi.org/10.1177/0007650309336451

Han, J. H., Bartol, K. M., \& Kim, S. (2015). Tightening up the performance-pay linkage: roles of contingent reward leadership and profit-sharing in the cross-level influence of individual pay-forperformance. Journal of Applied Psychology, 100(2), 417-430. http://dx.doi.org/10.1037/a0038282

Heavey, A. L., Holwerda, J. A., \& Hausknecht, J. P. (2013). Causes and consequences of collective turnover: a meta-analytic review. Journal of Applied Psychology, 98(3), 412-453. https://doi.org/10.1037/a0032380 
House, R. J., Hanges, P. M., Javidan, M., Dorfman, P., \& Gupta, V. (2004). Culture, leadership and organizations: the globe study of 62 societies. Thousand Oaks, CA: Sage.

Huselid, M. A. (1995). The impact of human resource management practices on turnover, productivity, and corporate financial performance. Academy of Management Journal, 38(3), 635-672. http://dx.doi.org/10.2307/256741

Inkinen, H. (2016). Review of empirical research on knowledge management practices and firm performance. Journal of Knowledge Management, 20(2), 230-257. http://dx.doi.org/10.1108/JKM-09-2015-0336

International Labour Organization. (1998). ILO Declaration of fundamental principles and rights at work. Retrieved from http://www.ilo.org/declaration/info/publications/WCMS_467653/lang-en/index.htm

Ionescu-Somers, A., Salzmann, O., \& Steger, U. (2005). The business case for corporate sustainability: literature review and research options. European Management Journal, 23(1), 27-36. http://dx.doi.org/10.1016/j.emj.2004.12.007

Jenkins, B. (2007). Expanding economic opportunity: the role of large firms [Initiative Report $\left.\mathrm{N}^{\mathrm{o}} 17\right]$. Kennedy School of Government, Harvard University, Cambridge, Massachusets, USA. Retrieved from https://www.hks.harvard.edu/mrcbg/CSRI/publications/report_17_EO\%20Framing\%20Paper\%20Final.pdf

Jensen, M. C. (1986). Agency costs of free cash flow, corporate finance and takeovers. American Economic Review, 76(2), 323-329. http://dx.doi.org/10.2139/ssrn.99580

Jones, D. A. (2010). Does serving the community also serve the company? Using organizational identification and social exchange theories to understand employee responses to a volunteerism programme. Journal of Occupational and Organizational Psychology, 83(4), 857-878. http://dx.doi.org/10.1348/096317909X477495

Judge, T. A., \& Bono, J. E. (2001). Relationship of core self-evaluations traits-self-esteem, generalized self-efficacy, locus of control, and emotional stability - with job satisfaction and job performance: a meta-analysis. Journal of Applied Psychology, 86(1), 80-92. https://doi.org/10.1037/00219010.86.1.80

Kacmar, K. M., Andrews, M. C., Van Rooy, D. L., Steilberg, R. C., \& Cerrone, S. (2006). Sure everyone can be replaced... but at what cost? Turnover as a predictor of unit-level performance. Academy of Management Journal, 49(1), 133-144. http://dx.doi.org/10.5465/AMJ.2006.20785670

Kim, S. Y., \& Park, H. (2011). Corporate social responsibility as an organizational attractiveness for prospective public relations practitioners. Journal of Business Ethics, 103(4), 639-653. https://doi.org/ 10.1007/s10551-011-0886-x

Lau, C. M. (2011). Team and organizational resources, strategic orientations, and firm performance in a transitional economy. Journal of Business Research, 64(12), 1344-1351. http://dx.doi.org/10.1016/j.jbusres.2011.01.001

Lee, C. H., \& Bruvold, N. T. (2003). Creating value for employees: investment in employee development. International Journal of Human Resource Management, 14(6), 981-1000. http://dx.doi.org/10.1080/0958519032000106173

Margolis, J. D., \& Elfenbein, H. A. (2008). Doing well by doing good: don't count on it. Harvard Business Review, 86(1), 19-20. 
McWilliams, A., Siegel, D., \& Wright, P. (2006). Corporate social responsibility: strategic implications. Journal of Management Studies, 43(1), 1-18. http://dx.doi.org/10.1111/j.14676486.2006.00580.x

Miles, M. P., \& Covin, J. G. (2000). Environmental marketing: a source of reputational, competitive, and financial advantage. Journal of Business Ethics, 23(3), 299-311. http://dx.doi.org/10.1023/A:1006214509281

Mitchell, T. R., Holtom, B. C., Lee, T. W., Sablynski, C. J., \& Erez, M. (2001). Why people stay, using job embeddedness to predict voluntary turnover. Academy of Management Journal, 44(6), 11021122. https://doi.org/10.2307/3069391

Neri, M., \& Soares, W. (2002). Desigualdade social e saúde no Brasil. Cadernos de Saúde Pública, 18, 77-87. https://dx.doi.org/10.1590/S0102-311X2002000700009

Orlitzky, M., Schmidt, F. L., \& Rynes, S. L. (2003). Corporate social and financial performance: a meta$\begin{array}{llll}\text { analysis. } & \text { Organization } & \text { Studies, } & \text { 403-441. }\end{array}$ http://dx.doi.org/10.1177/0170840603024003910

Peloza, J. (2009). The challenge of measuring financial impacts from investments in corporate social performance. Journal of Management, 35(6), 1518-1541. http://dx.doi.org/10.1177/0149206309335188

Peloza, J., \& Shang, J. (2011). How can corporate social responsibility activities create value for stakeholders? A systematic review. Journal of the Academy of Marketing Science, 39(1), $117-$ 135. http://dx.doi.org/10.1007/s11747-010-0213-6

Ployhart, R. E. (2004). Organizational staffing: a multilevel review, synthesis, and model. In J. J. Martocchio (Ed.), Research in personnel and human resources management (Vol. 23, pp. 121176). Oxford, UK: Elsevier.

Ployhart, R. E., \& Moliterno, T. P. (2011). Emergence of the human capital resource: a multilevel model. Academy of Management Review, 36(1), 127-150. http://dx.doi.org/10.5465/amr.2009.0318

Puppim, J. A. (2008). Empresas na sociedade: sustentabilidade e responsabilidade social. Rio de Janeiro: Elsevier.

Ree, M. J., \& Carretta, T. R. (2006). The role of measurement error in familiar statistics. Organizational Research Methods, 9(1), 99-112. http://dx.doi.org/10.1177/1094428105283192

Reis, C. N., \& Medeiros, L. E. (2007). Responsabilidade social das empresas e balanço social: meios propulsores do desenvolvimento econômico e social. São Paulo, SP: Atlas.

Rettab, B., Brik, A. B., \& Mellahi, K. (2009). A study of management perception of the impact of corporate social responsibility on organizational performance in emerging economics: the case of Dubai. Journal of Business Ethics, 89(3), 371-390. https://doi.org/10.1007/s10551-008-0005-9

Rynes, S. L., Gerhart, B., \& Parks, L. (2005). Personnel psychology: performance evaluation and pay for performance. Annual Review of Psychology, 56, 571-600. http://dx.doi.org/10.1146/annurev.psych.56.091103.070254

Silveira, A. (2004). Governança corporativa e estrutura de propriedade: determinantes e relação com o desempenho das empresas no Brasil (Tese de doutorado). Universidade de São Paulo, São Paulo, SP, Brasil.

Somaya, D., Williamson, I. O., \& Lorinkova, N. (2008). Gone but not lost: the different performance impacts of employee mobility between cooperators versus competitors. Academy of Management Journal, 51(5), 936-953. http://dx.doi.org/10.5465/AMJ.2008.34789660 
Tinoco, J. E. P. (2008). Balanço social: uma abordagem da transparência e da responsabilidade pública das organizações. São Paulo, SP: Atlas.

Turker, D. (2009). Measuring corporate social responsibility: a scale development study. Journal of Business Ethics, 85(4), 411-427. http://dx.doi.org/10.1007/s10551-008-9780-6

United Nations. (n.d.). The ten principles. Retrieved from http://www.unglobalcompact.org/AboutTheGC/TheTenPrinciples/index.html

Van der Laan, G. V., Ees, H. V., \& Witteloostuijn, A. V. (2008). Corporate social and financial performance: an extended stakeholder theory, and empirical test with accounting measures. Journal of Business Ethics, 79(3), 299-310. http://dx.doi.org/10.1007/s10551-007-9398-0

Van de Wiele, P. (2010). The impact of training participation and training costs on firm productivity in Belgium. The International Journal of Human Resource Management, 21(4), 582-599. http://dx.doi.org/10.1080/09585191003612083

Waddock, S. A. (2004). Parallel universes: companies, academics, and the progress of corporate citizenship. Business and Society Review, 109(1), 5-42. http://dx.doi.org/10.1111/j.00453609.2004.00002.x

Waldman, D. A., Sully de Luque, M., Washburn, N., House, R. J., Adetoun, B., Barrasa, A., Bobina, M., Bodur, M., Chen, Y-J., Debbarma1, S., et al. (2006). Cultural and leadership predictors of corporate social responsibility values of top management: a GLOBE study of 15 countries. $\begin{array}{llll}\text { Journal of International Business } & \text { Studies, }\end{array}$ http://dx.doi.org/10.1057/palgrave.jibs.8400230

Weber, M. (2008). The business case for corporate social responsibility: a company level measurement approach for CSR. European Management Journal, 26(4), 247-261. http://dx.doi.org/10.1016/j.emj.2008.01.006

Wernerfelt, B. (1984). A resource-based view of the firm. Strategic Management Journal, 5(2), 171180. http://dx.doi.org/10.1002/smj.4250050207

Wooldridge, J. M. (2002). Econometric analysis of cross section and panel data. Cambridge, MA: MIT Press.

World Bank. (2003). World development report 2004: making services work for poor people Overview. Washington, DC: World Bank Group. Retrieved from http://documents. worldbank.org/curated/en/527371468166770790/World-Development-Report2004-Making-services-work-for-poor-people-Overview

\section{Authors' Profiles}

Flávia Cavazotte

Rua Marquês de São Vicente, 225, 22451-900, Rio de Janeiro, RJ, Brazil. E-mail address: flavia.cavazotte@iag.puc-rio.br

Nicolas Corteze Chang

Rua Marquês de São Vicente, 225, 22451-900, Rio de Janeiro, RJ, Brazil. E-mail address: nikaum_resende@hotmail.com 